УДК 656.71.004.15

С.С. Дев'яткіна, к.т.н., доц.

\title{
НОРМУВАННЯ РИЗИКІВ У СИСТЕМІ КЕРУВАННЯ БЕЗПЕКОЮ ПОЛЬОТІВ НА АЕРОДРОМАХ ЦИВІЛЬНОЇ АВІАЦІЇ
}

Національний авіаційний університет

E-mail: lanasunshine@voliacable.com

Розглянуто проблему нормування ризиків у системі керування безпекою польотів на аеродромах цивільної авіації стосовно окремих підрозділів (служб). Обтрунтовано актуальність проблеми. Запропоновано шляхи до ї̈ вирішення.

The problem of risks normalization in safety management system on civil aviation aerodromes applied to the departments is considered. Its urgency is proved and the solution is suggested.

Рассмотрена проблема нормирования рисков в системе управления безопасностью полетов на аэродромах гражданской авиации для отдельных подразделений (служб). Обоснована ее актуальность. Предложены способы ее решения.

\section{Постановка проблеми}

3 огляду на аналіз стану безпеки польотів у світі Міжнародна організація цивільної авіації (ICAO) наголошує на першорядності вирішення проблем безпеки польотів та впровадженні нового підходу до керування безпекою польотів як на рівні держави, так i у всіх організаціях авіаційної галузі [1]:

- авіакомпаніях, аеродромах цивільної авіації;

- постачальників обслуговування повітряного руху;

- навчальних закладах, які здійснюють підготовку фахівців авіаційної галузі;

- організаціях $з$ проектування, технічного обслуговування та ремонту авіаційної техніки.

У документі ICAO [1] наведено вимогу щодо розроблення Державних програм з безпеки польотів для забезпечення прийнятного (нормованого) рівня безпеки польотів (ризику щодо безпеки польотів) у цивільної авіації.

Державна програма з безпеки польотів визначається як комплекс нормативних положень та видів діяльності, спрямованих на керування безпекою польотів у межах всієї держави.

(C) С.С. Дев'яткіна, 2011
Згідно 3 вказаною програмою державою встановлюються номенклатура та нормовані рівні показників безпеки польотів, що мають задовольнятися всіма організаціями-постачальниками обслуговування в авіаційній галузі.

Новітній підхід, що має підвищити якість обслуговування в авіаційній галузі в аспектах безпеки, полягає в розробленні та забезпеченні ефективного функціонування системи керування безпекою польотів (СКБП) на всіх авіаційних підприємствах.

Безпека - це стан системи, за якого ризик заподіяння шкоди здоров'ю осіб або майну знижено до нормованого рівня та підтримується на цьому або більш низькому рівні (прийнятному рівні) завдяки безперервному виявленню джерел небезпеки i контролю факторів небезпеки.

Згідно з документом ICAO [1], СКБП повинна забезпечувати:

- виявлення факторів небезпеки, що потенційно загрожують безпеці польотів;

- прийняття заходів, необхідних для підтримки нормованих показників безпеки польотів;

- моніторинг та регулярні визначення i оцінку показників безпеки польотів;

- постійне самовдосконалення та підвищення ефективності функціонування організації, у тому числі й у сфері безпеки польотів. 
Оцінювання показників безпеки польотів неможливе без встановлення їх номенклатури та нормованих значень, що мають забезпечуватися організацією в процесі функціонування.

Аеродром цивільної авіації $\epsilon$ складною системою, що забезпечує виконання багатьох функцій, але всі види його діяльності спрямовані на забезпечення безпеки польотів повітряних суден (ПС).

До складу сучасного аеродрому цивільної авіації входять сім основних підрозділів (служб) аеродрому, кожен 3 яких виконує ряд функцій, що забезпечують:

- зліт;

- кінцевий етап заходу на посадку;

- посадку ПС;

- пробіг по злітно-посадковій смузі;

- руління до місця стоянки;

- маневрування ПС на пероні;

- постановку ПС у док.

На аеродромі проводиться:

- технічне обслуговування ПС;

- обслуговування пасажирів та вантажу;

- обслуговування повітряного руху;

- комплекс заходів з авіаційної безпеки.

3 огляду на складність та розгалуженість такої організації, як аеродром, виникає проблема оцінки рівня безпеки польотів не тільки по аеродрому «в цілому», а й по окремих його функціональних підрозділах.

Кожен підрозділ, що бере участь у забезпеченні польотів ПС, має задовольняти певні вимоги щодо показників безпеки польотів.

Тільки у цьому випадку можливо:

- проаналізувати та оцінити діяльність кожної служби аеродрому;

- знайти іiі слабкі місця у забезпеченні безпеки польотів ПС;

- розробити заходи щодо підвищення ефективності функціонування кожної окремої служби;

- здійснювати керування рівнем безпеки польотів у всіх підрозділах аеродрому та на аеродромі в цілому.
Без розроблення номенклатури показників безпеки польотів та їх нормованих значень для кожної служби аеродрому неможливо проводити кількісну оцінку рівня безпеки польотів на аеродромі, а, отже, неможливе i ефективне функціонування системи керування безпекою польотів.

Мета роботи - розроблення методу нормування ризиків щодо безпеки польотів у СКБП на аеродромах цивільної авіації.

\section{Аналіз нормативних документів}

В Україні прийнято нормативний документ [2] 3 проблем безпеки польотів, який $€$ першим кроком у створенні Державної програми з безпеки польотів, як вимагає ICAO.

У державній цільовій програмі безпеки польотів на 2009-2015 pр. наголошується на тому, що рівень безпеки польотів в Україні не відповідає світовим вимогам і необхідно найближчим часом вжити всі можливі заходи для його підвищення.

Установлений у цьому документі нормований рівень ризику щодо безпеки польотів для ПС цивільної авіації становить 0,72 авіаційних подій та інцидентів на 100000 год нальоту ПС. Цільовим завданням з безпеки польотів $є$ зменшення цього показника на $50 \%$ до 2015 p.

Для досягнення поставленої мети необхідно проведення реформ у сфері безпеки польотів:

- впровадження нових теоретичних та практичних методів забезпечення безпеки польотів ПС;

- удосконалення існуючих систем забезпечення безпеки польотів у всіх авіаційних організаціях, в тому числі і аеродромах цивільної авіації;

- розроблення нормативно-правової бази в цій сфері;

- виділення додаткового цільового фінансування на потреби забезпечення безпеки польотів.

У стандартах та рекомендаціях ICAO [1] як основний захід з підвищення рівня безпеки польотів запропоновано розроблення та впровадження СКБП, що грунтується на концепції керування ризиком. 
На вимогу ICAO на всіх аеродромах цивільної авіації слід створити таку СКБП, що, 3 одного боку, забезпечить виконання всіх покладених на неї функцій, а 3 іншого боку, врахує всі індивідуальні особливості аеродрому (інтенсивність повітряного руху, кліматичну характеристику, параметри експлуатаційного мінімуму тощо), у тому числі і економічні.

У документах ICAO немає чіткої номенклатури показників безпеки польотів, методів нормування, методів визначення показників безпеки польотів у межах кожної авіаційної організації. Запропоновано тільки якісну оцінку показників безпеки польотів, хоча наголошується на тому, що вони мають виражатися в числовій формі, мають бути зрозумілими, вимірюваними i пов'язаними 3 проблемами безпеки польотів [3, п. 6.6.6].

Це протиріччя пояснюється тим, що розроблення числових методів визначення та нормування показників безпеки польотів $\epsilon$ складним завданням, що потребує застосування системного наукового підходу.

Якісне визначення та оцінка факторів небезпеки з застосуванням «матриці ризику», що пропонується у документі [3], грунтується на методі експертних оцінок, основним недоліком якого є суб' єктивність та низька точність. Він може використовуватися тільки, якщо застосування числових методів неможливо. В інших випадках слід уникати цього методу, адже він вносить похибку в функціонування системи, що за несприятливих обставин може мати фатальні наслідки.

Наприкінці 2009 р. фахівці Національного авіаційного університету створили проект Положення про систему управління безпекою польотів на аеродромах цивільної авіаії України [4].

\section{Нормування ризиків щодо безпеки польотів для окремих служб аеродрому}

Для кращого розуміння основних аспектів концепції керування ризиком у проекті Положення про систему керування безпекою польотів на аеродромах цивільної авіації України надаються такі визначення термінів.
Ризик - це комплексний показник безпеки польотів, що являє собою міру об' єктивної можливості виникнення авіаційної події, або серйозного інциденту, або інциденту в умовах появи та існування факторів небезпеки. Тобто це ймовірність того, що потенційні можливості факторів небезпеки спричинити авіаційну подію реалізуються.

Фактор небезпеки - будь-яка подія випадкового характеру, реалізація якої потенційно загрожує безпеці проведення операцій у зоні аеродрому.

Рівень безпеки польотів - показник, що кількісно характеризує безпеку польотів.

Рівень ризику щодо безпеки польотів показник, що кількісно характеризує ризик.

Поняття «рівень ризику щодо безпеки польотів» і «рівень безпеки польотів» $є$ зворотними поняттями.

Будь-який вид діяльності в авіаційній галузі пов'язаний $з$ певним ризиком, у тому числі і діяльність аеродрому під час забезпечення польотів ПС.

Політ ПС вважається безпечним, якщо на кожному його етапі не виникло факторів небезпеки, які б загрожували його успішному завершенню. Виникнення факторів небезпеки є випадковою подією, реалізація якої має ймовірнісний характер.

У випадку реалізації якого-небудь фактора небезпеки виникає ризик для успішного завершення польоту. Ступінь цього ризику залежить від характеристики фактора небезпеки та дій екіпажу ПС в умовах існування цього фактора небезпеки.

У свою чергу, дії екіпажу ПС, а особливо пілотів, самі по собі можуть стати фактором небезпеки, і тоді ймовірність успішного завершення посадки залежить від того, наскільки довго фактор небезпеки (помилка пілота) буде існувати і чи можна вжити заходів, щоб успішно завершити посадку після того, як фактор небезпеки припинить своє існування.

Факторами небезпеки можуть бути:

- кліматичні умови під час польоту;

- географічні умови в зонах зльоту, зниження та захід на посадку;

- відмови обладнання ПС; 
- відмови аеродромного обладнання;

- відмови (помилки) служби обслуговування повітряного руху.

Часто загрозу успішному завершенню польоту становить одночасна або послідовна реалізація кількох факторів небезпеки під час польоту ПС.

Для уникнення факторів небезпеки використовують різні методи, які постійно вдосконалюються і на яких грунтується захист системи від факторів небезпеки. Ці методи розвиваються в чотирьох основних напрямках:

- розроблення нормативних документів за окремими видами діяльності людини, в процесі якої можуть виникнути фактори небезпеки;

- методи підвищення надійності обладнання на етапах проектування та експлуатації, відмова якого може стати фактором небезпеки, наприклад, резервування обладнання;

- підтримання високого рівня професійної підготовки фахівців у відповідній галузі та створення для них належних умов праці;

- створення позитивної корпоративної культури на підприємстві з відповідною мотивацією кожного співробітника щодо підвищення рівнів безпеки польотів.
Сучасна СКБП аеродрому повинна грунтуватися на такій основній ідеї: якщо ризик неможливо усунути, його необхідно зменшити до мінімально можливого значення i створити такий захист у системі, щоб мінімізувати наслідки від його реалізації, тобто ризиком необхідно вміти керувати (див. рисунок).

Для ефективного керування будь-яким процесом, в тому числі процесом забезпечення безпеки польотів, необхідно:

- мати докладну інформацію стосовно поточного його стану;

- мати номенклатуру показників, що характеризують стан процесу та нормовані значення, яких треба досягти;

- вміти розробляти заходи щодо приведення показників стану системи у відповідність до нормованих значень за результатами оцінювання поточних значень показників.

Указані завдання, окрім другого, мають вирішуватися фахівцями з безпеки польотів в рамках СКБП на аеродромі.

Номенклатура показників безпеки польотів та відповідні їм нормовані значення мають бути затверджені на державному рівні відповідно до Державної програми з безпеки польотів або в нормативних документах.

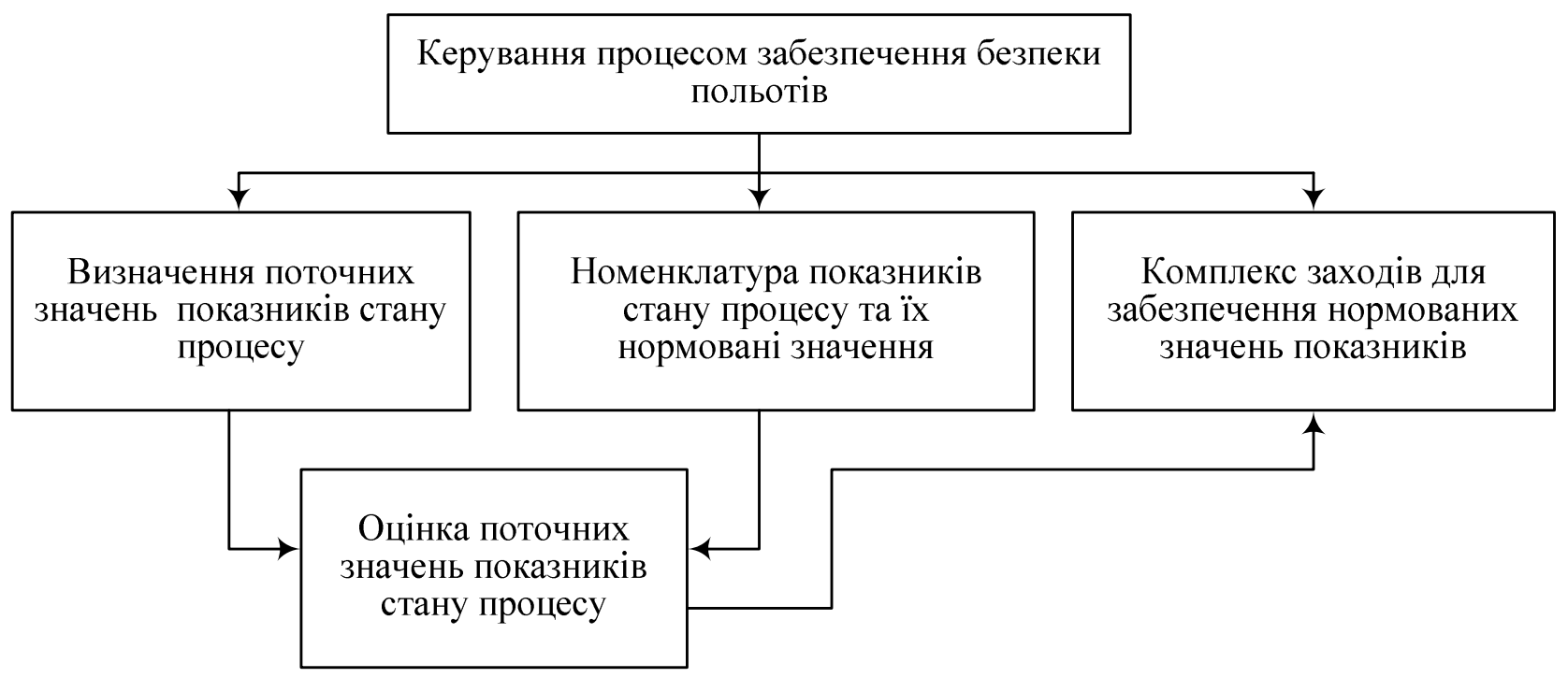

Загальна структура керування процесом забезпечення безпеки польотів 
Метод розроблення номенклатури показників безпеки польотів та їх нормованих значень запропоновано в роботі [5].

Номенклатуру показників безпеки польотів (ризиків щодо безпеки польотів) для аеродромів цивільної авіації та їх нормованих значень, що спираються на вимоги нормативних документів [1;2;3], наведено в таблиці.

\section{Нормовані значення ризиків авіаційних подій та інцидентів}

\begin{tabular}{|l|c|c|}
\hline \multirow{2}{*}{$\begin{array}{c}\text { Тип авіаційної } \\
\text { події/інциденту }\end{array}$} & \multicolumn{2}{|c|}{$\begin{array}{c}\text { Нормоване значення } \\
\text { ризиків }\end{array}$} \\
\cline { 2 - 3 } & $2009 \mathrm{p}$. & $2015 \mathrm{p}$. \\
\hline Катастрофа & $0,24 \cdot 10^{-6}$ & $0,12 \cdot 10^{-6}$ \\
Аварія & $0,24 \cdot 10^{-5}$ & $0,12 \cdot 10^{-5}$ \\
Серйозний інцидент & $0,72 \cdot 10^{-5}$ & $0,36 \cdot 10^{-5}$ \\
Інцидент & $0,14 \cdot 10^{-3}$ & $0,72 \cdot 10^{-4}$ \\
\hline
\end{tabular}

Аеродроми цивільної авіації повинні використовувати дані цієї таблиці як нормовані вимоги щодо рівнів ризиків виникнення авіаційних подій та інцидентів для загальної оцінки діяльності аеродрому з забезпечення безпеки польотів ПС. Вони можуть також встановлювати інші значення, які повинні бути не більше тих, що надаються державою, як нормовані (прийнятні або задані рівні безпеки польотів для певного аеродрому).

Однак тільки загальної оцінки недостатньо. Необхідно оцінювати ризики щодо безпеки польотів через діяльність кожного підрозділу аеродрому, окремих його служб.

Кожна служба аеродрому вносить свій індивідуальний внесок у загальну справу забезпечення безпеки польотів ПС.

Метод нормування ризиків від діяльності окремих служб аеродрому грунтується на системному аналізі структури аеродрому, технологічного процесу забезпечення польотів на аеродромі та вимогах стандартів і рекомендацій ICAO та складається з чотирьох етапів [1].

На першому етапі проводиться аналіз структури аеродрому, основне завдання якого визначити всі служби, що беруть участь у процесі забезпечення польотів ПС.
До складу типового аеродрому цивільної авіації України входять такі служби, що забезпечують польоти ПС.

Аеродромна служба забезпечує стан злітної смуги, прийнятний для здіснення польотів ПС.

Служба радіотехнічного забезпечення польотів забезпечує приведення ПС до аеродрому та його зниження до висоти прийняття рішення під час посадки.

Служба світлотехнічного забезпечення польотів забезпечує етап візуального пілотування вдень та вночі у складних метеорологічних умовах.

Служба метеорологічного забезпечення польотів визначає та надає інформацію щодо значень параметрів експлуатаційного мінімуму аеродрому та основну метеорологічну інформацію (швидкість та напрямок вітру, атмосферний тиск тощо).

Орнітологічна служба сприяє відсутності птахів у зоні аеродрому, вільної від перешкод.

Аварійно-рятувальна служба запобігає переходу аварії, що сталося на аеродромі, у катастрофу (тушіння пожежі, евакуація пасажирів тощо).

Служба авіаційної безпеки забезпечує недопущення несанкціонованого перебування об' єктів у межах льотної смуги.

Діяльність інших служб аеродрому, що стосуються обслуговування пасажирів та вантажу, технічного обслуговування ПС, організації обслуговування повітряного руху в зоні аеродрому або не чинить прямого впливу на безпеку польотів, або вони повинні мати свої окремі СКБП. Такі служби входять до складу інших організацій, що мають окремі СКБП, наприклад, організація з обслуговування повітряного руху, яка територіально базується на аеродромі.

На другому етапі проводиться визначення всіх факторів небезпеки для кожної служби аеродрому, діяльність якої впливає на рівень безпеки польотів. 
Взагалі фактори небезпеки мають визначатися для кожної служби аеродрому, що бере участь у забезпеченні польотів ПС. Ця процедура повинна проводитися фахівцями відповідної служби під наглядом спеціаліста з безпеки польотів в рамках функціонування СКБП на аеродромі.

Процедуру визначення факторів небезпеки періодично повторюють для пошуку нових факторів небезпеки, які не були визначені в результаті попереднього аналізу.

Усі фактори небезпеки за причиною походження можна класифікувати на чотири типи:

- технічне;

- організаційне;

- нормативне;

- соціальне.

До факторів небезпеки технічного походження відносяться відмови обладнання, що використовується в процесі забезпечення польотів (радіотехнічні системи точного/неточного заходу на посадку, світлосигнальне обладнання, реєстратори видимості тощо).

Відмови обладнання можуть бути двох типів:

- відмови, інформація про які стає відомою одразу через специфічність типу відмови або завдяки системі контролю;

- відмови, інформація про які надходить через деякий час у результаті операцій із періодичного технічного обслуговування обладнання.

Указані типи відмов треба обов'язково розділяти, оскільки вони чинять різний вплив на рівень безпеки польотів.

До факторів небезпеки організаційного походження відносять:

- порушення інструкцій персоналом служби, спричинені неналежними умовами праці людини на робочому місці;

- каральною політикою організації у сфері безпеки польотів;

- недостатньою мотивацію працівників;

- негативним прикладом поведінки керівництва.
До факторів небезпеки нормативного походження відносять недосконалість нормативних документів як державного рівня, так i аеродромних інструкцій, положень, наявність у них суперечливих вимог.

До факторів небезпеки соціального походження належать:

- ненавмисне порушення інструкцій персоналом служби - помилки людини, спричинені неналежним рівнем підготовки, нестачею досвіду, недостатньою кваліфікацією працівників, у тому числі у сфері безпеки польотів.

На третьому етапі проводиться якісна оцінка факторів небезпеки та їх класифікація 3 позицій важкості наслідків від реалізації.

Після визначення всіх можливих, навіть малоймовірних факторів небезпеки, необхідно:

- провести їх якісну оцінку для визначення важкості наслідків, що можуть бути спричинені в разі реалізації кожного фактора небезпеки та їх можливих комбінацій;

- прийняти до уваги супутні умови, що можуть спричинити той або інший розвиток подій з погляду їх впливу на безпеку польотів.

Для кожної служби аеродрому необхідно класифікувати фактори небезпеки за чотирьма ознаками, відповідно номенклатури показників безпеки польотів (див. таблицю), які потенційно можуть привести до катастроф, аварій, серйозних інцидентів, інцидентів.

Потім слід визначити кількість служб, фактори небезпеки яких потенційно приводять до певного типу авіаційних подій або інцидентів.

Докладне визначення та оцінку всіх факторів небезпеки необхідно провести для подальшого керування ними. Однак для цілей нормування достатньо визначити тільки ті фактори небезпеки, що призводять до найважчих наслідків.

Наприклад, за результатами аналізу етапу візуального пілотування ПС з використанням світлосигнальної системи аеродрому як 
фактори небезпеки від діяльності служби світлотехнічного забезпечення польотів можна вважати такі фактори:

- відмова обладнання світлосигнальної системи аеродрому типу «відмова $-\epsilon$ інформація про відмову»;

- відмова обладнання світлосигнальної системи аеродрому типу «відмова - немає інформації про відмову»;

- помилки або порушення інструкцій персоналом служби.

До найважчих наслідків приводить відмова типу «немає інформації про відмову», яка може спричинити встановлення хибного візуального контакту і потенційно привести до інциденту/серйозного інциденту та навіть до аварії або катастрофи.

Відмова світлосигнальної системи аеродрому типу «є інформація» потенційно може привести до інциденту/серйозного інциденту, а за умови реалізації супутнього фактора небезпеки - заходу на посадку «критичного ПС» або при помилкових діях екіпажу -до авіаційної події.

Такий фактор небезпеки, як помилки або порушення інструкцій персоналом служби світлотехнічного забезпечення польотів, може сприяти реалізації перших двох факторів небезпеки.

Подібний аналіз факторів небезпеки необхідно провести для кожної служби аеродрому, оскільки до інциденту або серйозного інциденту може привести хоча б один фактор небезпеки.

Таким чином, до інциденту або серйозного інциденту можуть привести фактори небезпеки від діяльності всіх служб аеродрому.

Кількість основних служб аеродрому $N_{\mathrm{c}}$ дорівнює семи.

На четвертому етапі проводиться визначення нормованих значень ризиків від реалізації окремих факторів небезпеки для кожної служби аеродрому на основі таких припущень.

1. Діяльність усіх служб аеродрому, що безпосередньо впливають на рівень безпеки польотів, є однаково важливою.
2. Фактори небезпеки від діяльності деяких служб необхідно розглядати разом із супутніми факторами небезпеки:

- дії екіпажу ПС;

- метеорологічні умови;

- факт, що ПС є «критичним» потребує термінової посадки через відмови обладнання ПС, нестачу палива тощо.

Нормоване значення ризику виникнення інциденту через реалізацію $i$-го фактора небезпеки для $j$-ї служби аеродрому $R_{\text {с.н.i. }}(i, j)$ розраховують за формулою

$$
R_{\text {с.н.і }}(i, j)=1-\sqrt[N_{\text {c.i. }}]{1-R_{\text {н.і }}},
$$

де $N_{\text {c.i }}$ - кількість служб аеродрому, реалізація факторів небезпеки від діяльності яких потенційно може привести до інциденту;

$R_{\text {н. і }}$ - нормований рівень ризику виникнення інциденту (див. таблицю).

Подібним чином визначаються ризики виникнення серйозних інцидентів, аварій та катастроф. У випадку, коли до негативних наслідків призводить не тільки $i$-й фактор небезпеки від діяльності $j$-ї служби, а і супутні $k$-і фактори небезпеки, формула (1) для авіаційної події набуває вигляду:

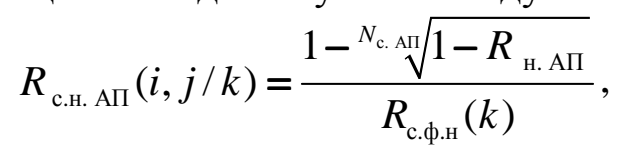

де $N_{\text {c. АП. }}$ - кількість служб аеродрому, реалізація фактора небезпеки від діяльності яких потенційно може привести до авіаційної події ПС;

$R_{\text {н. АП }}-$ нормований рівень ризику виникнення авіаційної події (аварії або катастрофи);

$R_{\text {с.ф.н }}(k)$ - ризик, спричинений реалізацією $k$-го супутнього фактора небезпеки.

Для аварійно-рятувальної служби аеродрому необхідно розглядати ймовірність переходу аварії в катастрофу через фактори небезпеки, спричинені діяльністю цієї служби.

Формула визначення нормованого значення ризику катастрофи $R_{\text {a.-....н. }}(i / l, \ldots, m)-$ через реалізацію $i$-го фактора небезпеки, спричиненого діяльністю аварійно-рятувальної служби за умови реалізації $l$-го 
фактора небезпеки або сукупності факторів $(l, \ldots, m)$, що призвели до аварії ПС, матиме такий вигляд:

$$
R_{\text {а.р. с. н. }}(i / l, \ldots, m)=\frac{1-\sqrt[N_{\text {с.к. }}]{1-R_{\text {н. к. }}}}{R_{\text {н. а. ПС }}(l, \ldots, m)},
$$

де $N_{\text {с. к. }}$ - кількість служб аеродрому, реалізація факторів небезпеки від діяльності яких потенційно може привести до катастрофи $\Pi$ П;

$R_{\text {н. к. }}-$ нормований рівень ризику виникнення катастрофи (див. таблицю);

$R_{\text {н. а. пс }}(l, \ldots, m)$ - нормований рівень ризику виникнення аварії ПС через реалізацію $l$-го фактора небезпеки або сукупності факторів $(l, \ldots, m)$.

Таким чином, визначаються нормовані значення показників безпеки польотів (ризиків) згідно з затвердженою номенклатурою для кожної служби аеродрому.

У межах функціонування СКБП фахівцями з безпеки польотів указані нормовані значення ризиків повинні використовуватися для оцінки діяльності з забезпечення польотів кожної служби аеродрому.

У випадку незабезпечення службою вказаних нормованих вимог повинні бути проаналізовані причини цього факту та розроблені відповідні організаційно-технічні заходи 3 підвищення якості функціонування служби щодо забезпечення безпеки польотів.

Нормовані вимоги 3 безпеки польотів для структурних підрозділів аеродрому повинні переглядатися згідно з запропонованим методом у випадку зміни нормованих значень показників безпеки польотів (ризиків), що встановлюються державою або аеродромом.

\section{Висновки}

Запропоновано метод вирішення актуальної проблеми нормування показників безпеки польотів (ризиків щодо безпеки польотів) для структурних підрозділів аеродромів цивільної авіації.

Вирішення цієї проблеми забезпечить функціонування механізму оцінки діяльності аеродромів щодо окремих їх служб у процесі забезпечення польотів ПС.

Запропонований метод вирішення проблеми сприятиме впровадженню та ефективному функціонуванню СКБП на аеродромах цивільної авіації України.

\section{Література}

1. Приложение 14 к Конвенции о Международной организации гражданской авиации. Аэродромы: В 2 т.: Т. 1. Проектирование и эксплуатация аэродромов. - Монреаль, 2009. - 350 с. - [ІСАО. Международные стандарты и рекомендуемая практика]. Режим доступу: http://www.aviadocs.net/ icaodocs/Annexes/an14_v1_5ed_cons_ru.pdf

2. Кониепиія Державної цільової програми безпеки польотів на 2009-2015 рр. від 05 березня 2009 р. № 273-p // Офіційний вісник України. - 2009. - № 20. - ст. 651.

3. Руководство по управлению безопасностью полетов, Doc 9859, AN/474. - Монреаль, 2009. - 316 с. [ICАО. Международные стандарты и рекомендуемая практика].

4. Положення про СУБП на аеродромах цивільної авіації України: наук.-досл. робота № 160 (643-х09) від 02.11.2009 р / НАУ; кер. В.М. Синєглазов; відп. викон. С.С. Дев’яткіна. - № ДР 110U001028. - № обліку 0210U003586.

5. Дев'яткіна С.С. Проблеми нормування ризиків щодо безпеки польотів на аеродромах цивільної авіації / С.С. Дев’ яткіна // Вісник НАУ. - 2010. - № 4. - С. 147-152. 